Grimlund, K. (1963). Acta Medica Scandinavica, Suppl. No. 405. Gobry, A. Z., and Edwards, K. D. G. (1968). American fournal of Medicine, 45, 43.

Gyorry, A. Z., Stewart, J. H., George, C. R. P., Tiller, D. J., and Edwards, K. D. G. (1969)., Quarterly fournal of Medicine. In press. Harrow, B. R. (1967). Fournal of Urology, 97, 203.

Healy, J. K., Edwards, K. D. G., and Whyte, H. M. (1964). fournal of Clinical Pathology, 17, 557 .,

Hultengren, N. (1961). Acta Chirurgica Scandinavica, Suppl. No. 277.

Kincaid-Smith, P. (1967). Lancet, 1, 859.

Kincald-Smith, P., Saker, B. M., McKenzie, I. F. C., and Muriden, K. D. (1968). Medical fournal of Australia, 1, 203.

Kleeman, C. R., Hewitt, W. L., and Guze, L. B. (1960). Medicine (Baltimore), 39, 3.
Pearson, H. H. (1967). Medical fournal of Australia, 2, 308.

Raisz, L. G., Au, W. Y. W., and Scheer, R. L. (1959). Fournal of Clinical Investigation, 38, 8.

Reynolds, T. B., and Edmondson, H. A. (1963). Fournal of the American Medical Association, 184, 435 .

Sanerkin, N. G (1966), British fournal of Urology, 38, 361.

Spühler, O., and Zollinger, H. U. (1953). Zeitschrift für klinische Medizin, 151,1 .

Steele, T. W., Edwards, K. D. G., and Györy, A. Z. (1968). Australasian Annals of Medicine, 17, 353 .

Wrong, O., and Davies, H. E. F. (1959). Quarterly Journal of Medicine, 28, 259.

Zak, G. A.; Brun, C., and Smith, H. W. (1954). Fournal of Clinical Investigation, 33, 1064.

\title{
Clinical Trial of Emepronium Bromide in Nocturnal Frequency of Old Age
}

\author{
J. C. BROCKLEHURST,* M.D., M.R.C.P.ED., M.R.C.P.GLASG. ; J. B. DILLANE, $†$ M.B., F.R.C.S. \\ JOHN FRY, $\dagger$ M.D., F.R.C.S. ; P. ARMITAGE, $\ddagger$ PH.D.
}

British Medical fournal, 1969, 2, 216-218

\begin{abstract}
Summary : A double-blind cross-over trial of emepronium bromide (Cetiprin) in nocturnal frequency of micturition in a group of elderly women living in their homes showed that the drug was superior to placebo in diminishing urinary frequency, though not every person benefited. It is suggested that the drug may alter the established habit of rising at night to pass urine. Side-effects were negligible.
\end{abstract}

\section{Introduction}

Nocturnal frequency of micturition is one of the trials of old age. In a previous paper (Brocklehurst, Dillane, Griffiths, and Fry, 1968) we have shown it to be present in $64 \%$ of the total elderly population $(70 \%$ of males and $61 \%$ of females of 65 years and over). Its presence is not related to urinary infection and it may be assumed that this symptom often results from diminished bladder capacity associated with the characteristics of the uninhibited neurogenic bladder. We have shown (Brocklehurst and Dillane, 1966) by cystometrogram that such characteristics are often present in non-incontinent elderly women.

It is therefore reasonable to attempt to treat nocturnal frequency with drugs known to have some effect on the uninhibited neurogenic bladder. A double-blind cross-over trial of such a drug-emepronium bromide (Cetiprin)-is reported.

Emepronium bromide was synthesized in Stockholm in the early 1950s and was found to possess both a synapse-blocking action and an inhibitory effect on peripheral autonomic cholinergic nerves. Its pharmacology has been described by Hansson and Schmiterlöw (1961). Its effect on the urinary bladder was reported by Jönsson and Zederfeldt (1957). They showed by cystometrogram that emepronium bromide increased bladder capacity by an average of $20 \%$ in normal subjects and by an even greater amount in a number of participants with neurogenic bladder disorders. The effect on nocturnal frequency

\footnotetext{
- Consultant Physician in Charge of Bromley and Sidcup Geriatric Service.

+ General Practitioner, Beckenham, Kent.

$\ddagger$ Professor of Medical Statistics, London School of Hygiene and Tropical
} Medicine, London W.C.1. in old age has been studied (but not on a double-blind basis) by K. Hallen (personal communication, 1967), who showed satisfactory results in 75 to $80 \%$ of cases.

\section{Methods}

The subjects in the present trial were selected from women in one general practice whom we had found in our previous survey to have nocturnal frequency of micturition (Brocklehurst et al., 1968). They were thus selected by direct questioning and not because they were reporting symptoms of dysuria. Urinary infection was diagnosed by bacterial count of 100,000 or more per ml. Its presence did not exclude the patient from the trial. No specific treatment was given for infection during the period of the trial.

The trial lasted six weeks and was supervised by a Stateregistered nurse. It was divided into three two-week periods. During weeks 1 and 2 the participants received no treatment but recorded their habit of retiring and of rising to pass urine during the night. During weeks 3 and 4 they took tablets marked A and in weeks 5 and 6 tablets marked B. A and B were randomly allocated to the drug and an identical placebo, the allocation for any one participant remaining unknown to the participant, nurse, and physician.

Participants were instructed to take three tablets before retiring. Each active tablet contained $50 \mathrm{mg}$. of emepronium bromide, thus a nightly dose of $150 \mathrm{mg}$. was taken. The nurse visited each participant seven times, once to begin the recording, and then at weekly intervals for six further visits. On each of these visits she collected the records of the previous week and supplied the tablets for the participant to take during the next week. The nurse recorded the following data: (1) whether the participant felt that her night rest during the week was " better than," "the same as," or "worse than" the preceding week; (2) how many tablets were returned during each of weeks 3 to 6-that is, number not taken; and (3) whether the tablets had upset the participant and, if so, in what ways.

Every morning of the six-week period each participant recorded, on a special card, the number of times she had micturated during the preceding night. These cards were collected weekly by the nurse. 


\section{Analysis of Results}

Thirty-four participants were entered into the trial. One was admitted to hospital after week 1 and therefore did not receive either form of treatment; her records are not considered any further in the analysis. Of the remaining 33,17 (group $\mathrm{X}$ ) received the placebo first and 16 (group $\mathrm{Y}$ ) received the drug first.

For five participants the records of nightly frequency were incomplete (one in group $\mathrm{X}$ and four in group $\mathrm{Y}$ ). Of these five with incomplete records, one complained of vertigo after week 3 (first week on drug), one complained of lower abdominal pain after week 5 (first week on drug), one was withdrawn after week 2 at the request of her family, one became "ill and unsteady" during week 5 (first week on placebo) and her condition improved after discontinuation of treatment, and one had no records for the first control week but co-operated fully during the four weeks of active therapy.

Participants in groups $\mathrm{X}$ and $\mathrm{Y}$ were similar in age and the presence or absence of urinary infection (Table I). Participants providing incomplete records did not show any unusual features.

TABLE I.-Characteristics of Participants Before Trial Period (Excluding

\begin{tabular}{|c|c|c|c|c|}
\hline & & & $\begin{array}{c}\text { Group X. } \\
\text { Placebo, Drug }\end{array}$ & $\underset{\text { Drug, Placebo }}{\text { Group Y. }}$ \\
\hline $\begin{array}{c}\text { Age in } \\
\text { years }\end{array}$ & $\begin{cases}\text { Less than } & 70 \\
70-79 & \ldots \\
80- & \ldots\end{cases}$ & $\underline{.}$ & \begin{tabular}{l|l}
2 & \\
8 & 16 \\
6 &
\end{tabular} & $\left.\begin{array}{l}0 \\
6 \\
6\end{array}\right\} 12$ \\
\hline $\begin{array}{l}\text { Urinary } \\
\text { infection }\end{array}$ & $\left\{\begin{array}{l}\text { Prresent } \\
\text { Absent } \\
\text { Unknown }\end{array}\right.$ & $\begin{array}{l}\ddot{2} \\
\because \ddot{ }\end{array}$ & \begin{tabular}{r|l}
14 & 16
\end{tabular} & \begin{tabular}{l|l}
3 \\
9 \\
0
\end{tabular} \mid 12 \\
\hline
\end{tabular}

\section{Comparison of Two Treatments}

\section{Frequency of Micturition}

The mean number of times participants with complete records rose to pass urine per night during the three fortnightly periods are shown in Table II. When the placebo preceded the drug there was little effect in the mean number of voidings during the placebo period. However, when the drug was given first there was a reduction of $25 \%$ in the number of voidings, and this reduction persisted during the subsequent placebo period. It thus appeared that the drug's effect continued after its administration was stopped. Such a carry-over effect might be due to persistence of the drug in the body because of slow excretion, or it might be the result of a new pattern being established in the participant's habit of rising at night to pass urine. Normally, emepronium is almost fully excreted by the body in 24 hours. Thus there is no reason to expect a cumulative effect. Some degree of renal failure is, of course, possible in these elderly women, and this we did not investigate. It seems unlikely, however, that renal failure sufficient to have such an effect would have passed unnoticed. The second hypothesis, therefore, seems to us the more probable and suggests that short courses of the drug, producing maximum benefit, may be used instead of continuous therapy. This requires further investigation. TABLE II.-Moan Frequency of Micturition of All Participants (Groups
X and Y) During Each Two-weekly Period

\begin{tabular}{c|c|c|c|c|c}
\hline \multirow{2}{*}{ Group } & Order & \multicolumn{3}{|c|}{$\begin{array}{c}\text { Mean Frequency. } \\
\text { Weeks: }\end{array}$} & $\begin{array}{c}\text { No. of } \\
\text { Participants }\end{array}$ \\
\cline { 2 - 6 } & & $1-2$ & $3-4$ & $5-6$ & \\
\hline $\mathrm{X}$ & Control, placebo, drug & 2.38 & 2.29 & 1.95 & 16 \\
\hline
\end{tabular}

\section{Differences in Total Voidings}

To test the significance of the difference in mean voidings between placebo and drug shown above in the third and fourth weeks we took, for each participant, the difference in total frequency between weeks 1 and 2 (control period) and weeks 3 and 4 (either placebo or drug period). For this purpose we can include two of the participants with incomplete records, since in these two cases records were complete to at least the end of week 4. The distribution of these differences is shown in Table III. Here it is seen that the mean change in the 17 participants in group $\mathrm{X}$ is $-1 \cdot 18$. This is not significantly different from zero-that is, the change from control to placebo periods had no effect on frequency. On the other hand, the mean change in the 13 participants in group $\mathrm{Y}$-from control to drug-is significantly negative $(-6 \cdot 31)$. The difference between the two mean changes is significant $(P<0.02)$. There is reason, therefore, to believe that the drug had a real effect.

TABLE III.-Distribution of Change in Total Frequency From One Two-week Period (Weeks 1 and 2) to Another (Weeks 3 and 4) Negative Changes Being Reductions in Frequency

\begin{tabular}{|c|c|c|}
\hline \multirow[b]{2}{*}{ Change } & \multicolumn{2}{|c|}{ No. of Participants } \\
\hline & $\begin{array}{l}\text { Group X. } \\
\text { Control followed } \\
\text { by Placebo }\end{array}$ & $\begin{array}{l}\text { Group Y. } \\
\text { Control followed } \\
\text { by Drug }\end{array}$ \\
\hline $\begin{array}{r}-15 \text { to }-19 \\
-11 \text { to }-14 \\
-6 \text { to }-10 \\
-1 \text { to }-5 \\
0 \text { to } \\
5 \text { to } \\
10 \text { to } \\
14\end{array}$ & $\begin{array}{l}0 \\
1 \\
2 \\
7 \\
5 \\
2 \\
0\end{array}$ & $\begin{array}{l}1 \\
3 \\
3 \\
3 \\
3 \\
0 \\
0\end{array}$ \\
\hline $\begin{array}{c}\text { Total } \\
\text { Mean change }\end{array}$ & $\begin{array}{l}17 \\
-1 \cdot 18\end{array}$ & $\begin{array}{l}13 \\
-6 \cdot 31\end{array}$ \\
\hline
\end{tabular}

Difference between the mean changes is significant, $\mathrm{P}<0.02$.

The effect was, however, by no means universally observed. Three of the 13 participants receiving the drug in weeks 3 and 4 showed no change or an increase in frequency (Table III).

If we compare weeks 3 and 4 with weeks 5 and 6 a similar picture emerges. The analysis is possible ón 16 participants in group $\mathrm{X}$ and on 13 in group $\mathrm{Y}$. The distributions of the changes in total frequency from one two-week period to the other are shown in Table IV. Group $X$ shows a general reduction in frequency with the change from placebo to drug. Group Y shows no systematic change. Again the difference between the two mean changes $(-4.75$ and -0.62$)$ is significant $(P<0.02)$, the drug being superior to the placebo. There is, however, individual variation.

TABLE IV.-Distributions of Change in Total Frequency From One Two-week Period (Weeks 3 and 4) to Another (Weeks 5 and 6), Negative Changes Being Reductions in Frequency

\begin{tabular}{|c|c|c|}
\hline \multirow[b]{2}{*}{ Change } & \multicolumn{2}{|c|}{ No. of Participants } \\
\hline & $\begin{array}{c}\text { Group X. } \\
\text { Placebo followed } \\
\text { by Drug }\end{array}$ & $\begin{array}{c}\text { Group Y. } \\
\text { Drug followed } \\
\text { by Placebo }\end{array}$ \\
\hline $\begin{array}{r}-15 \text { to }-19 \\
-11 \text { to }-14 \\
-6 \text { to }-10 \\
-1 \text { to }-5 \\
0 \text { to } \\
5 \text { to } \\
\end{array}$ & $\begin{array}{r}1 \\
1 \\
2 \\
10 \\
2 \\
0 \\
\end{array}$ & $\begin{array}{l}1 \\
0 \\
0 \\
5 \\
5 \\
2\end{array}$ \\
\hline $\begin{array}{l}\text { Total ... } \\
\text { Mean change } . .\end{array}$ & $\begin{array}{l}16 \\
-4 \cdot 75\end{array}$ & $\begin{array}{l}13 \\
-0.62\end{array}$ \\
\hline
\end{tabular}

Difference between the mean changes is significan $t, P<0.02$.

\section{Side-effects}

Two participants complained of constipation on both drug and placebo. One participant given the drug complained of abdominal pain and another of vertigo-neither completed the course. On the placebo one complained of headache, one of blurred vision, and one felt ill and unsteady. The third participant did not complete the course. There is no clear indication of a higher incidence of adverse effects on the drug 
than on the placebo. The weekly question, "Did the tablets upset you ?" was usually answered " no." It was answered "yes" by two participants during treatment with the drug and by one participant during the placebo treatment.

\section{Participants' Other Comments}

General comments were not invariably made by the participants. Where clear statements of improvement or no improvement on either drug were made they are summarized in Table V. The results clearly support those in Table II.

\begin{tabular}{|c|c|c|c|c|}
\hline \multirow[b]{2}{*}{ Group } & \multicolumn{4}{|c|}{ Improvement on } \\
\hline & $\begin{array}{l}\text { Both Drug } \\
\text { and Placebo }\end{array}$ & $\begin{array}{l}\text { Drug } \\
\text { Only }\end{array}$ & $\begin{array}{c}\text { Placebo } \\
\text { Only }\end{array}$ & $\begin{array}{l}\text { Neither Drug } \\
\text { nor Placebo }\end{array}$ \\
\hline $\begin{array}{l}\text { Placebo followed by drug } \\
\text { Drug followed by placebo }\end{array}$ & $\begin{array}{l}0 \\
3\end{array}$ & $\begin{array}{l}6 \\
2\end{array}$ & $\begin{array}{l}0 \\
2\end{array}$ & $\begin{array}{l}6 \\
3\end{array}$ \\
\hline
\end{tabular}

\section{Conclusion}

This trial showed that emepronium bromide given in dosage of $150 \mathrm{mg}$. on going to bed effectively diminished nocturnal frequency of micturition in aged women. On the basis of a double-blind cross-over trial an important difference emerged between those participants given the placebo before the drug and those given the drug first. In the first case there is little effect with the placebo but a moderate effect with the drug. In the latter case there is a more marked effect with the drug, and this is carried over into the placebo period.

The difference between control period and active drug when compared with the difference between the control period and the placebo is statistically significant $(P<0.02)$. This effect is borne out by participants' own observations of the drug.

As we have found with other drugs used on the neurogenic bladder of old age (Brocklehurst and Dillane, 1967), not every person is benefited. There are some in whom no effect is observed. In such a case the drug should be withdrawn after three to four weeks.

No side-effect of importance was observed. Such side-effects as were recorded were distributed evenly between the drug and the placebo.

It may be concluded, therefore, that emepronium bromide is worthy of trial in any elderly woman whose sleep is disturbed by nocturnal frequency. Some will show no effect, most will show a moderate diminution or complete disappearance of the frequency. It is probable that $150 \mathrm{mg}$. on retiring is a low dose and that a further $100 \mathrm{mg}$. may be taken during the night if the participant awakens. Extra dosage should be introduced gradually.

We have not investigated the drug with males. We believe that nocturnal frequency in men as in women is commonly due to the uninhibited neurogenic bladder of old age, and will respond equally well to emepronium bromide. The enlarged prostate, however, is an additional hazard in the elderly male and caution is required in using any anticholinergic drug in males with prostatic enlargement because of the danger of precipitating acute urinary retention.

Our thanks are due especially to Mrs. H. Billing, S.R.N., who carried out the field work on which this trial is based; also to Mr. A. N. Nicholls and Kabi Pharmaceuticals Limited for their considerable help in organizing and financing this trial ; to Miss M. Chandler for statistical assistance; and to Dr. Louis Griffiths for arranging the bacteriological tests.

\section{REFERENCES}

Brocklehurst, J. C., and Dillane, J. B. (1966). Gerontologia Clinica, 8,

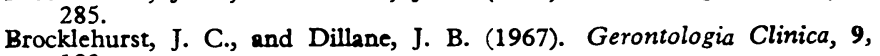
182.

Brocklehurst, J. C., Dillane, J. B., Griffiths, L., and Fry, J. (1968), Gerontologia Clinica, 10, 242.

Hansson, E., and Schmiterlów, C. G. (1961). Acta Pharmacologica et Toxicologica, 18, 183

Jönsson, G., and Zederfeldt, B. (1957). Urologia Internationalis, 4, 293.

\title{
Herpes Zoster and Multiple Sclerosis*
}

\author{
J. A. R. LENMAN, $\dagger$ M.B., CH.B., F.R.C.P.ED. ; T. J. PETERS, $\ddagger$ M.B., M.SC., M.R.C.P.
}

$S^{n+}$ mmary : No significant difference was found between 50 consecutive patients with multiple sclerosis and matched controls in respect of previous infection with rubella or measles and chicken-pox, or of previous vaccination and immunizing injections. Significantly more patients had a past history of herpes zoster compared with the controls.

\section{Introduction}

In a previous paper (Ross, Lenman, and Rutter, 1965) it was shown that patients with multiple sclerosis had significantly higher antibody titres to varicella-zoster virus as compared with matched controls. Antibody to a number of viruses was found in a greater number of cases than controls, but the difference was significant only in respect of varicella-zoster. In the present study a series of cases of multiple sclerosis, many of whom were included in the previous study, and carefully matched controls were questioned concerning a past history of chicken-pox (varicella) and shingles (zoster), and also about previous illnesses suggestive of infection with rubella, measles, poliomyelitis, and glandular fever, and about previous vaccination and immunization injections.

* Based on a paper presented to the Association of British Neurologists on 6 April 1968.

† Senior Lecturer in Neurology, Department of Medicine, University of Dundee.

₹Lecturer, Department of Medicine, University of Dundee. Present address: The Royal Postgraduate Medical School, London W.12. 